\title{
Dolomite and Micronutrient Fertilizer Affect Phosphorus Fate in Pine Bark Substrate used for Containerized Nursery Crop Production
}

\section{Jacob H. Shreckhise \\ USDA, Agricultural Research Service \\ Application Technology Research Unit \\ 1680 Madison Avenue \\ Wooster, OH 44691}

James S. Owen, Jr.*

School of Plant \& Environmental

Sciences

Virginia Tech

Hampton Roads Agricultural Research

\& Extension Center

1444 Diamond Springs Road

Virginia Beach, VA 23455
Matthew J. Eick

School of Plant \& Environmental

Sciences

185 Ag Quad Lane

236 Smyth Hall

Virginia Tech, Blacksburg, VA 24061

Alexander X. Niemiera

School of Plant \& Environmental

Sciences

409 West Campus Drive

401-A Saunders Hall

Virginia Tech, Blacksburg, VA 24061
James E. Altland

USDA, Agricultural Research Service

Application Technology Research Unit

1680 Madison Avenue

Wooster, OH 44691

Sarah A. White

Department of Plant \& Environmental

Sciences

Clemson Univ.

E-143 Poole Agricultural Center

Clemson, SC 29634

\section{Core Ideas}

- Addition of dolomite or micronutrients reduced leachate-P from bark-based substrates.

- Orthophosphate-P from controlledrelease fertilizer contributed 74 to $86 \%$ of TDP.

- Dolomite reduced fertilizer orthophosphate-P in leachate by $>\mathbf{5 0} \%$.

- $\mathrm{MnHPO}_{4}$ and $\mathrm{Ca}_{5}\left(\mathrm{PO}_{4}\right)_{3}(\mathrm{OH})$ were dominant modeled solid-phase species in leachate.

- Addition of dolomite and micronutrient amendments to bark may be considered a BMP.

Dolomite and a micronutrient fertilizer are routinely incorporated into a pine bark-based soilless substrate when producing containerized nursery crops, yet the effect of these amendments on phosphorus $(P)$ is not well understood. The objective of this research was to determine the effect of dolomite and micronutrient fertilizer amendments on $\mathbf{P}$ partitioning among four $\mathbf{P}$ fractions (i.e., orthophosphate-P [OP], non-orthophosphate dissolved P [NODP], total dissolved $\mathbf{P}[$ TDP], and particulate $\mathbf{P}[\mathrm{PP}]$ ) and to model potential $\mathbf{P}$ species in leachate of pine bark substrate. Amendment treatments incorporated into bark at experiment initiation included (1) a control (no fertilizer, dolomite, or micronutrient fertilizer), (2) controlled-release fertilizer (CRF), (3) CRF and dolomite, (4) CRF and micronutrient fertilizer, or (5) CRF, dolomite, and micronutrient fertilizer. Phosphorus fractions in leachate of irrigated pine bark columns were determined at eight sampling times over 48 days. Amending pine bark with dolomite and micronutrient fertilizer reduced leachate OP concentrations by $70 \%$ when averaged across sampling dates primarily due to retention of OP in the substrate by dolomite. The NODP fraction was unaffected by amendments, and the response of TDP was similar to that of OP. Particulate $P$ was present throughout the study and was strongly correlated particulate Fe and DOC concentrations. Visual MINTEQ indicated $\mathrm{MnHPO}_{4}$ and $\mathrm{Ca}_{5}\left(\mathrm{PO}_{4}\right)_{3}(\mathrm{OH})$ were consistently saturated with respect to their solid phase in treatments containing CRF. Results of this study suggest amending pine bark with dolomite and micronutrients is a best management practice for reducing $\mathbf{P}$ leaching from containerized nurseries.

\footnotetext{
Abbreviations: CRF, controlled-release fertilizer; DAI, days after initiation; DOC, dissolved organic carbon; EC, electrical conductivity; F, fertilizer-only; FL, fertilizer plus dolomite; FLM, fertilizer plus dolomite plus micronutrients; FM, fertilizer plus micronutrients; NODP, non-orthophosphate dissolved phosphorus; OP, orthophosphate-phosphorus; PP, particulate phosphorus; TDP, total dissolved phosphorus; TP, total phosphorus.
}

This publication is a portion of a dissertation submitted by Jacob $\mathrm{H}$. Shreckhise in partial fulfillment of the degree of Doctor of Philosophy. The use of trade or brand names in this publication does not constitute a guarantee or warranty of the product by Virginia Tech and does not imply its approval to the exclusion of other products or vendors that also may be suitable. Soil Sci. Soc. Am. J. 83:1410-1420 doi:10.2136/sssaj2018.12.0493 Received 21 Dec. 2018.

Accepted 1 July 2019.

*Corresponding author (jim.owen@vt.edu).

(C) 2019 The Author(s). Re-use requires permission from the publisher. 
U nderstanding the chemical fate of $\mathrm{P}$ fertilizers is critical for determining $P$ bioavailability and its potential effect on down-stream ecosystems. Eutrophication and subsequent toxic algae blooms induced by elevated $\mathrm{P}$ concentrations is a global issue affecting surface water used for human consumption, irrigation, fisheries, and recreation (Carpenter et al., 1998). Agriculture is the leading source of $P$ contamination in US surface waters (USEPA, 2017). In mineral soils, interactions between fertilizer-P and soil components have been thoroughly examined; however, little research has assessed the chemical fate of fertilizer P in organic substrates, specifically milled pine bark, used to produce container-grown crops.

In the United States, containerized woody crops contribute $63 \%$ of all nursery stock sales (USDA, 2014), and pine bark (Pinus taeda L.) is the predominant substrate utilized in the eastern USA for container-grown nursery crops (Bilderback et al., 2013b; Lu et al., 2006). Pine bark has limited ability to sorb P (Marconi and Nelson, 1984; Paradelo et al., 2017; Yeager and Wright, 1982); consequently, soluble P fertilizers rapidly leach from pine bark-filled containers during irrigation (Cole and Dole, 1997; Godoy and Cole, 2000; Yeager and Barrett, 1984, 1985a, 1985b). Phosphorus leaching from containers is exacerbated since container-grown crops are typically irrigated daily while the plants are actively growing. The use of polymer- or resin-coated controlled-release fertilizers (CRFs), a best management practice (Bilderback et al., 2013a) that reduces P leaching relative to soluble fertilizers (Broschat, 1995; Diara et al., 2014), has been widely adopted by the US nursery industry according to survey studies (Dennis et al., 2010; Fain et al., 2000; Mack et al., 2017). However, P uptake efficiency (percent of fertilizer-P absorbed by plants) of container-grown nursery crops remains between 7 and 62\% when using CRFs (McGinnis et al., 2009; Owen et al., 2008; Tyler et al., 1996; Warren et al., 1995, 2001).

Pine bark has an initial $\mathrm{pH}$ range of 4.0 to 4.3 ; yet, optimal plant nutrient availability in organic substrates occurs when $\mathrm{pH}$ is 5.0 to 5.5 (Bunt, 1988). Accordingly, pine bark is routinely amended with a liming agent, such as dolomite $\left[\mathrm{CaMg}\left(\mathrm{CO}_{3}\right)_{2}\right]$, to increase $\mathrm{pH}$ and supply plants with $\mathrm{Ca}$ and $\mathrm{Mg}$. However, the effects of dolomite on P solubility in pine bark substrate has not been assessed. Multiple studies have reported dolomite sorption of OP in aqueous solution (Karaca et al., 2004, 2006; Mangwandi et al., 2014; Xu et al., 2014; Yuan et al., 2014, 2015). For example, in batch sorption experiments, Yuan et al. $(2014,2015)$ found that $10 \mathrm{~g}$ of dolomite removed up to $98 \% \mathrm{P}$ from $1 \mathrm{~L}$ of solution containing $50 \mathrm{mg} \mathrm{L}^{-1}$ P. Karaca et al. (2006) reported rapid sorption of $\mathrm{OP}$ by dolomite in solution, with equilibration occurring within 15 to 30 min depending on initial OP concentration. Xu et al. (2014) utilized attenuated total reflectance Fourier transform infrared (ATR-FTIR) spectroscopy, $\mathrm{x}$-ray absorption near edge structure (XANES) spectroscopy, and diffuse layer modeling to investigate $\mathrm{P}$ speciation on calcite and dolomite. When solution $\mathrm{pH}$ values were varied from 5.0 to 7.0 and $\mathrm{OP}$ concentrations were 2 or $10 \mathrm{mg} \mathrm{L}^{-1}$, which are common conditions in pore-water of dolomite-amended pine bark substrate for nursery-crop pro- duction (Bilderback et al., 2013a), the authors determined that sorbed OP on the surface of dolomite was primarily in the form of $\mathrm{Mg}$ and $\mathrm{Ca}$ surface complexes and $\mathrm{Ca}-\mathrm{P}$ secondary minerals.

Evidence of OP sorption by liming agents has also been observed in organic container-substrates. Amending peat-based substrates with varying rates of $\mathrm{Ca}(\mathrm{OH})_{2}$ was shown to reduce $\mathrm{P}$ leaching from containers by $20 \%$ (Haynes, 1982) to $88 \%$ (Havis and Baker, 1985) compared to substrates without $\mathrm{Ca}(\mathrm{OH})_{2}$. Two studies by Argo and Biernbaum (1996a, 1996b) reported that the amount of soluble $\mathrm{OP}$ in a peat-based substrate amended with various forms of dolomite was inversely related to the substrate $\mathrm{pH}$. For example, Argo and Biernbaum (1996a) measured OP concentrations in saturated media extracts (Warncke, 1986) after growing Impatiens walleriana Hook. F. fertilized with $20 \mathrm{mg} \mathrm{L}^{-1} \mathrm{P}$ for 16 wk in a Sphagnum peat-based substrate containing $1.5 \mathrm{~kg} \mathrm{~m}^{-3}$ microfine $\mathrm{Ca}(\mathrm{OH})_{2} \cdot \mathrm{MgO}$ or $8.4 \mathrm{~kg} \mathrm{~m}^{-3} \mathrm{CaCO}_{3} \cdot \mathrm{MgCO}_{3}$. In both lime treatments, substrates with $\mathrm{pH}$ values of about 5.0 and $8.1 \mathrm{had}$ OP concentrations of $\sim 21$ and $3 \mathrm{mg} \mathrm{L}^{-1}$, respectively. Argo and Biernbaum (1996a) speculated that the reduction in soluble OP was due to precipitation of $\mathrm{P}$ as $\mathrm{CaHPO}_{4}$ or $\mathrm{CaH}_{5} \mathrm{O}_{6} \mathrm{P}$. However, the effect of liming agents, specifically dolomite, on $\mathrm{P}$ leaching from pine bark substrate has not been thoroughly investigated.

In addition to amending organic substrates with a liming agent, growers commonly add a granular micronutrient fertilizer. Iron is a primary constituent of many micronutrient fertilizers and is often supplied in chelated form or as $\mathrm{FeSO}_{4}$. Ferrous sulfate, a compound used to remove $\mathrm{P}$ from wastewater (Strickland, 1998), can reduce OP solubility via $\mathrm{Fe}-\mathrm{PO}_{4}$ precipitation (Moore and Miller, 1994; Rich, 2005; Tasistro and Kissel, 2006) and OP sorption to humic substances via Fe bridges (Gerke and Hermann, 1992; Weir and Soper, 1963). Many Fe-PO 4 precipitates are water-insoluble (Sanyal and De Datta, 1991) and thus unavailable for plant-uptake. Current understanding of Fe-P interactions in pine bark-based substrates is based on pioneering research conducted by Handreck (1991a, 1991b, 1992, 1996) who analyzed the effect of $\mathrm{FeSO}_{4}$ application rate on $\mathrm{P}$ concentrations in diethylenetriaminepentaacetic acid (DTPA) extracts. Although results from all four studies indicated that $\mathrm{FeSO}_{4} 7 \mathrm{H}_{2} \mathrm{O}$ reduces DTPA-extractable $\mathrm{P}$ concentrations in pine bark-based substrates, these results may have been confounded by the $\mathrm{CaCO}_{3}-$ based liming agent used to maintain a constant $\mathrm{pH}$ across $\mathrm{FeSO}_{4}$ treatments. Similar to dolomite, $\mathrm{CaCO}_{3}$ can sorb OP (Xu et al., 2014); presumably, treatments containing more $\mathrm{FeSO}_{4}$, which acidifies pore-water during hydrolysis, would have required more $\mathrm{CaCO}_{3}$ to achieve the same substrate $\mathrm{pH}$ as treatments with less $\mathrm{FeSO}_{4}$. Accordingly, the reported lower $\mathrm{P}$ concentrations in pine bark containing more $\mathrm{FeSO}_{4}$ may have been partially due to $\mathrm{P}$ sorption by $\mathrm{CaCO}_{3}$. Hence, reinvestigating the effect of sulfated micronutrient fertilizer on water-extractable $\mathrm{P}$ species and concentration in pine bark would provide insight into determining $\mathrm{P}$ fertilization recommendations and environmental implications of $\mathrm{P}$ leached from containerized crops.

In natural waters, $\mathrm{P}$ fractions (e.g., total $\mathrm{P}[\mathrm{TP}]$, total dissolved $\mathrm{P}[\mathrm{TDP}]$, particulate $\mathrm{P}[\mathrm{PP}]$, and $\mathrm{OP}$ ) are commonly de- 
termined to assess the threat of $\mathrm{P}$ to water quality (Worsfold et al., 2016). Since only OP is available for plant uptake, fractioning $\mathrm{P}$ in soil-water extracts provides insight into P lability. Despite the importance of $\mathrm{P}$ fractions on surface water quality and plant availability of $\mathrm{P}$, to our knowledge, $\mathrm{PP}, \mathrm{TDP}, \mathrm{OP}$, and non-orthophosphate dissolved P (NODP) concentrations and the impact of dolomite and micronutrient fertilizer on these $P$ fractions has not been studied in effluent or water-extracts of pine bark substrate with incorporated CRF. Accordingly, the objectives of our study were to (i) determine the effect of CRF, dolomite, and micronutrient fertilizer amendments on OP, NODP, TDP, and PP concentrations in leachate of pine bark substrate; and (ii) examine potential precipitated $P$ species in pine bark leachate using the geochemical speciation software, Visual MINTEQ.

\section{MATERIALS AND METHODS}

Stabilized pine bark (milled through a $12.7-\mathrm{mm}$ screen) was attained from Pacific Organics (Henderson, NC) on 15 Jan. 2016. Measured air space, container capacity, and available water (by volume) of the substrate were 40,40 , and $27 \%$, respectively, and bulk density was $0.15 \mathrm{~g} \mathrm{~cm}^{-3}$ (NCSU porometer method; Fonteno et al., 1995). Substrate particle size distribution (by weight) was $72 \%$ coarse ( $>2$ $\mathrm{mm}$ ), $16 \%$ medium (2.0 to $0.5 \mathrm{~mm}$ ), and $12 \%$ fine $(<0.5 \mathrm{~mm}$ ). Pinebark elemental analysis was determined by Brookside Laboratories (New Bremen, $\mathrm{OH}$ ) using a Thermal 6500 Duo inductively coupled plasma optical emission spectrometer (ICP-OES) following microwave-assisted, nitric acid digestion (Peters et al., 2003). The substrate was comprised of $0.29 \mathrm{~g} \mathrm{~kg}^{-1} \mathrm{~N}, 0.01 \mathrm{~g} \mathrm{~kg}^{-1} \mathrm{P}, 0.14 \mathrm{~g} \mathrm{~kg}^{-1} \mathrm{~K}, 0.29 \mathrm{~g} \mathrm{~kg}^{-1} \mathrm{Ca}$, $0.05 \mathrm{~g} \mathrm{~kg}^{-1} \mathrm{Mg}, 0.03 \mathrm{~g} \mathrm{~kg}^{-1} \mathrm{~S}, 6.2 \mathrm{mg} \mathrm{kg}^{-1} \mathrm{~B}, 1321 \mathrm{mg} \mathrm{kg}^{-1} \mathrm{Fe}$, $117.4 \mathrm{mg} \mathrm{kg}^{-1} \mathrm{Mn}, 6.3 \mathrm{mg} \mathrm{kg}^{-1} \mathrm{Cu}, 27.5 \mathrm{mg} \mathrm{kg}^{-1} \mathrm{Zn}$, and the $\mathrm{C}$ to N ratio was 176.

One day prior to experiment initiation, pine bark was amended with $4.75 \mathrm{~kg} \mathrm{~m}^{-3}$ of a homogeneous, 5 to $6 \mathrm{mo}$ (release based on a $27^{\circ} \mathrm{C}$ ) CRF (Polyon 19-2.6-10 [as N-P $2 \mathrm{O}_{5}-\mathrm{K}_{2} \mathrm{O}$ ], Harrell's, Lakeland, FL) and one of four amendment treatments: (1) $4.15 \mathrm{~kg} \mathrm{~m}^{-3}$ dolomite (FL), (2) $0.89 \mathrm{~kg} \mathrm{~m}^{-3}$ granular micronutrient fertilizer (FM), (3) both dolomite and micronutrient fertilizer (FLM), or (4) neither dolomite nor micronutrient fertilizer (F; i.e., CRF-only). In addition, non-amended pine bark without $\mathrm{CRF}$ was included as a control. The CRF was composed of $\mathrm{NH}_{4} \mathrm{NO}_{3}, \mathrm{NH}_{4} \mathrm{H}_{2} \mathrm{PO}_{4}$, and $\mathrm{K}_{2} \mathrm{SO}_{4}$. For the FL and FLM substrate treatments, dolomite was supplied as $50 \%$ pulverized dolomite $\left(94 \% \mathrm{CaCO}_{3}\right.$ equivalent [CCE], Old Castle Lawn and Garden, Thomasville, PA) and 50\% ground dolomite (97\% CCE, Rockydale Quarries Corporation, Roanoke, VA). The pulverized dolomite had 100, 95, 72, and 54\% and the ground dolomite had $100,90,50$ and $35 \%$ passing through 2.00-, 0.84-, 0.25-, and 0.15$\mathrm{mm}$ mesh screens, respectively. Collectively, the dolomite mixture contained 21\% Ca and 22\% Mg by weight. The granular micronutrient fertilizer (Micromax, Everris, Dublin, $\mathrm{OH}$ ) contained 6.00\% Ca, 3.00\% Mg, $12.00 \% \mathrm{~S}, 0.10 \% \mathrm{~B}, 1.00 \% \mathrm{Cu}, 17.00 \% \mathrm{Fe}$, $2.50 \% \mathrm{Mn}, 0.05 \% \mathrm{Mo}$, and $1.00 \% \mathrm{Zn}$ derived from $\mathrm{CaMg}\left(\mathrm{CO}_{3}\right)_{2}$, $\mathrm{FeSO}_{4} \cdot 1 \mathrm{H}_{2} \mathrm{O}, \mathrm{MnSO}_{4}, \mathrm{ZnSO}_{4}, \mathrm{CuSO}_{4} \cdot 5 \mathrm{H}_{2} \mathrm{O}, \mathrm{Na}_{2} \mathrm{~B}_{4} \mathrm{O}_{7}$, and $\mathrm{Na}_{2} \mathrm{MoO}_{4} \cdot 2 \mathrm{H}_{2} \mathrm{O}$. The CRF and substrate amendments were in- corporated into the pine bark by hand-mixing for $2 \mathrm{~min}$ to ensure homogeneity without damaging CRF granules.

Twenty columns were constructed of $30-\mathrm{cm}$ sections of polyvinyl chloride (PVC) pipe ( $7.8 \mathrm{~cm}$ i.d.; $8.9 \mathrm{~cm}$ o.d.), and the bottom of each column was fastened with a PVC flat cap with 20 evenly distributed, 8-mm, circular holes. Precision-woven, monofilament, 500- $\mu$ m mesh fabric (Sefar Propyltex 05-500/36, Heiden, Switzerland) was placed between the bottom end-cap and column to prevent substrate from falling through or clogging the 8 -mm holes. The top of each column was affixed to a PVC coupler which was used to elevate diffusers $5 \mathrm{~cm}$ above the substrate surface. Diffusers were PVC flat caps with 16 evenly distributed, 2-mm holes and were used to evenly disperse irrigation water over the substrate surface, minimizing preferential flow. A diagram of the column assembly can be found in Hoskins et al. (2014), labeled "unsaturated column". A high-density polyethylene (HDPE) funnel was positioned beneath each column to direct leachate into individual 250-mL HDPE bottles.

For each substrate treatment and the control, four columns (i.e., replicates) were packed with $1400 \mathrm{~cm}^{3}$ substrate to achieve a mean bulk density of $0.145 \mathrm{~g} \mathrm{~cm}^{-3}\left(\sim 0.02 \mathrm{~g} \mathrm{~cm}^{-1}\right.$ vertical variation within a column) and mounted vertically in a randomized complete block design with two rows of ten columns. The experiment was blocked to account for filtration time within a sampling date and laboratory climate differences (mean air temperature of $22.4 \pm 0.33^{\circ} \mathrm{C}[\mathrm{SE}]$ ), which could affect CRF release of nutrients. Using a GEVA 75 controller with a latch solenoid and hydraulic valve (G75-C-1W-61, Baccara Automation Control, Bayswater, Victoria, $A U)$, each column received a single daily aliquot of tap water from a pressure compensating emitter $\left(2.2 \pm 0.01 \mathrm{~mL} \mathrm{~s}^{-1}\right.$; 01WPCLL8, Netafim, Fresno, CA) fastened to $127 \mathrm{~mm}$ polyethylene tubing $2 \mathrm{~cm}$ above each diffuser. At experiment initiation (Day 0$)$, each column was irrigated for $228 \mathrm{~s}(\sim 500 \mathrm{~mL})$; for 48 $\mathrm{d}$ thereafter, columns were automatically irrigated every $24 \mathrm{~h}$ for $57 \mathrm{~s}(\sim 125 \mathrm{~mL}$ or $2.6 \mathrm{~cm})$. The intent of the initial high-volume irrigation event was to settle substrate particles and mimic standard nursery practices following pot-up of a crop. Irrigation water, collected periodically over the course of the experiment $(n=8)$, contained (mg L${ }^{-1} \pm \mathrm{SE}$ ): $0.21 \pm 0.01 \mathrm{P}, 13.5 \pm 0.49 \mathrm{Ca}, 5.77$ $\pm 0.20 \mathrm{Mg}, 1.33 \pm 0.12 \mathrm{~K}, 11.5 \pm 0.49 \mathrm{Na},<0.01 \mathrm{Fe},<0.20 \mathrm{Al}$, $18.7 \pm 0.54 \mathrm{Cl}, 1.99 \pm 0.09 \mathrm{~S}, 0.38 \pm 0.04 \mathrm{Zn}$, and $<0.02 \mathrm{~B}, \mathrm{Mn}$, and $\mathrm{Cu}$. Alkalinity of the irrigation water at experiment termination $(n=3)$ was $55.9 \mathrm{mg} \mathrm{L}^{-1} \pm 0.7$ (Brookside Laboratories). The daily irrigation volume of $125 \mathrm{~mL}$ was determined after conducting a preliminary study which showed $125 \mathrm{~mL}$ displaced enough substrate pore-water for subsequent analyses while minimally diluting leachate with the fresh tap water. Average leachate-volume $(100 \pm 0.05 \mathrm{~mL})$ was measured from each column $12 \mathrm{~h}$ after irrigating to ensure leaching was consistent across treatments.

On Days 1, 2, 5, 6, 9, 10, 15, 16, 23, 24, 31, 32, 41, 42, 47, and 48 , a $20-\mathrm{mL}$ aliquot of leachate from each column and the irrigation water was analyzed for $\mathrm{pH}$ and electrical conductivity (EC) using a benchtop meter (HI5521-01, Hanna Instruments, Woonsocket, RI) within $4 \mathrm{~h}$ of sample collection (i.e., within $16 \mathrm{~h}$ 
of irrigation). Concentrations of ions (i.e., $\mathrm{PO}_{4}^{3-}, \mathrm{NO}_{3}{ }^{-}, \mathrm{NO}_{2}{ }^{-}$, $\mathrm{Cl}^{-}$and $\left.\mathrm{NH}_{4}^{+}\right)$, dissolved $(<0.45 \mu \mathrm{m})$ organic carbon (DOC), and total and dissolved $(<0.45 \mu \mathrm{m})$ elements (i.e., $\mathrm{B}, \mathrm{Ca}, \mathrm{Cu}, \mathrm{Fe}$, $\mathrm{K}, \mathrm{Mg}, \mathrm{Mn}, \mathrm{Mo}, \mathrm{Na}, \mathrm{Ni}, \mathrm{P}, \mathrm{S}$, and $\mathrm{Zn}$ ) were determined from 2-d composite samples. The first half of each composite sample was collected on Days 1, 5, 9, 15, 23,31, 41, and 47, and were prepared as follows. For samples in which leachate ion concentrations were determined, $3 \mathrm{~mL}$ leachate were syringe-filtered within $12 \mathrm{~h}$ of collection into a 10 -mL glass vial using a 60 -mL Luer-Lok syringe (26300, Exel International Medical Products, St. Petersburg, FL) and $0.2-\mu \mathrm{m}$ hydrophilic polyvinylidene fluoride (PVDF) disposable syringe-filters. Filters of $0.2 \mu \mathrm{m}$ pore size were used to reduce possible sorption of OP to Fe colloids in the 0.45 to $0.2 \mu \mathrm{m}$ size range (Sinaj et al., 1998). The $0.2-\mu \mathrm{m}$ filters were then replaced with $25 \mathrm{~mm}$ Swinnex filter holders (SX0002500, Millipore Sigma, Burlington, MS), each containing a $0.45 \mu \mathrm{m}$ PVDF membrane (HVLP02500, Millipore Sigma), to filter $13.5 \mathrm{~mL}$ and $10 \mathrm{~mL}$ leachate into respective 60 -mL HDPE bottles. The $13.5 \mathrm{~mL}$ filtered sample ( $27 \mathrm{~mL}$ composite), which was ultimately analyzed for dissolved organic carbon (DOC) concentration, was acidified to a $\mathrm{pH}<3$ with two drops of $2 \mathrm{~mol} \mathrm{~L}^{-1} \mathrm{HCl}$ to remove inorganic carbon from samples via volatilization. The filtered $10-\mathrm{mL}$ sample (20-mL composite) was later analyzed for dissolved element concentrations. Ten $\mathrm{mL}$ of non-filtered leachate was dispensed into a 60-mL HDPE bottle within $12 \mathrm{~h}$ of collection for eventual determination of total concentrations of elements. Samples were refrigerated at $8^{\circ} \mathrm{C}$ until the reminder of the composite sample was added the following day (Days 2, 6, 10, 16, 24, 32, 42, or 48). The 6-mL, $27-\mathrm{mL}$ and two $20-\mathrm{mL}$ composite samples were then stored at ${ }^{-} 30^{\circ} \mathrm{C}$. Non-filtered samples were later thawed and digested according to the method described in QuikChem Method 10-115-01-4-B, except sample volume and amount of digestion reagent added to samples was reduced by half. After digestion, white sediment was present in some samples; thus, digested samples were filtered through a $0.2-\mu \mathrm{m}$ PVDF filter before being stored at $8^{\circ} \mathrm{C}$.

Analysis of leachate ion concentrations was accomplished using two ion chromatography (IC) systems. The IC systems used to determine anion concentrations (ICS-2100, ThermoFisher Scientific) and cation concentrations (ICS-1600, ThermoFisher Scientific) utilized respective $4 \mathrm{~mm}$ by $250 \mathrm{~mm}$ (i.d. $\times$ length) anion- and cation-exchange columns (AS19 and CS12A, respectively, Thermo Fisher Scientific) at $35^{\circ} \mathrm{C}$ and an autosampler (AS-AP, Thermo Fisher Scientific) on a $25 \mu \mathrm{L}$ sample loop. The ICS-2100 was equipped with a metal trap column (MFC-1, Thermo Fisher Scientific) to facilitate detection of the anions. Total and dissolved element concentrations were determined with optical emission spectrometry (iCAP 6300 Duo View ICP-OES Spectrometer; Thermo Fisher Scientific). Dissolved organic carbon (non-purgeable organic carbon from organic sources that is available for microbial metabolic functions) concentrations were analyzed via NPOC/TN analysis using a Shimadzu TOC-V $\mathrm{V}_{\mathrm{CPH}}$ total organic carbon analyzer with TNM-1 TN measuring unit (Shimadzu Scientific Instruments, Kyoto, Japan).

\section{Model Analysis}

Theoretical chemical P speciation in leachate was modeled using Visual MINTEQ, a geochemical speciation software (Gustafsson, 2013). Input parameters included $\mathrm{pH}$, DOC (NICA-Donnan model), $\mathrm{PO}_{4}{ }^{3-}, \mathrm{NH}_{4}{ }^{+}, \mathrm{NO}_{2}{ }^{-}, \mathrm{NO}_{3}{ }^{-}, \mathrm{B}(\mathrm{III})$, $\mathrm{Ca}^{2+}, \mathrm{Cl}^{-}, \mathrm{Cu}^{2+}, \mathrm{Fe}^{3+}, \mathrm{K}^{+}, \mathrm{Mg}^{2+}, \mathrm{Mn}^{2+}, \mathrm{Mo}(\mathrm{VI}), \mathrm{Na}^{+}, \mathrm{Ni}^{2+}$, $\mathrm{SO}_{4}{ }^{2-}$, and $\mathrm{Zn}^{2+}$ concentrations. Element input values were based on concentrations measured in previously described filtered samples. Metals were assumed to be in their oxidized state. Carbonate concentrations were estimated based on measured irrigation water alkalinity as well as $\mathrm{Ca}$ and $\mathrm{Mg}$ concentrations in leachate of substrates containing dolomite and/or micronutrient fertilizer. Electrical conductivity was equated to ionic strength using the formula proposed by Alva et al. (1991; i.e., ionic strength $=[E C \times 0.012]-0.0002)$ and compared to ionic strengths calculated by Visual MINTEQ to ensure consistency. Saturation indices provided in output were used to interpret degree of saturation in solutions with respect to solid phases.

\section{Statistics}

Phosphorus fraction partitioning in the particulate versus dissolved phases was analyzed via three-way analysis of variance (ANOVA) with a repeated measures factor (time) and two between-subjects factors, substrate (F, FL, FM, and FLM) and fraction (PP [i.e., TP - TDP] and TDP). Dissolved Fe $(<0.45 \mu \mathrm{m})$ and particulate $\mathrm{Fe}$ (i.e., total $\mathrm{Fe}$ - dissolved $\mathrm{Fe}$ ) concentrations were analyzed in the same manner. The dissolved $\mathrm{P}$ phase was further assessed in a separate, but similar, analysis that included fractions, OP and NODP (i.e., TDP - OP) instead of PP and TDP. For all three-way ANOVA, the three-way interaction (time $\times \mathrm{P}$ fraction $\times$ substrate), three two-way interactions (time $\times$ fraction, time $\times$ substrate, and fraction $\times$ substrate), and three main effects were assessed. Concentrations of other elements were equivalent between filtered and non-filtered samples $(p>0.05)$; thus, analyses were performed using dissolved (i.e., filterable) concentration values. Effects of substrate, time, and the substrate $\times$ time interaction on $\mathrm{Ca}, \mathrm{EC}, \mathrm{DOC}$, and $\mathrm{pH}$ were analyzed via two-way repeated measures ANOVA. The block effect (random) was non-significant $(p>0.05)$ in all ANOVA and therefore removed from analysis to simplify the model.

Prior to analysis, data were transformed to correct for heteroscedasticity and non-normality. The log-transformation was used for $\mathrm{Ca}, \mathrm{Mg}, \mathrm{EC}$, and DOC values, and the normalized Johnson's transformation (Johnson, 1949) was used for all Fe and $P$ data. Repeated measures analysis was executed by modeling covariance structures (Wolfinger, 1993). The most appropriate covariance structure was selected by fitting data to various homogeneous and heterogeneous covariance structures available in JMP Pro 14 (SAS Institute Inc., Cary, NC) and comparing corrected Akaike information criterion $\left(\mathrm{AIC}_{\mathrm{c}}\right)$ values. According to $\mathrm{AIC}_{\mathrm{c}}$ values, the following covariance structures were selected for repeated measures analyses: homogeneous antidependent for $\mathrm{P}$ (PP vs. TDP fractions), $\mathrm{Fe}, \mathrm{Ca}$, and $\mathrm{Mg}$; heterogeneous antidependent for $\mathrm{P}$ (OP vs. NODP fractions); first-order autoregressive 
(AR[1]) for EC and DOC; and unequal variance for $\mathrm{pH}$ data.

When interactions were significant $(p<0.05)$, simple effects were analyzed using Tukey's Honest Significant Difference (HSD) to compare fertilized substrates. The control was excluded from the multiple-comparison procedure to ensure power of the test to accurately detect differences between the effect of amendments when a CRF was present. Dunnett's test was used to contrast values of the non-fertilized control to those of each substrate treatment containing CRF. Correlations were assessed using the Pearson correlation coefficient $(r)$. Percent reduction in element concentrations by amended substrates, discussed hereafter, were calculated on the basis of concentrations in the F substrate unless otherwise noted. All data were processed using JMP Pro 14 (SAS Institute Inc., Cary, NC).

\section{RESULTS AND DISCUSSION Calcium}

Calcium concentrations were affected by a substrate $\times$ time interaction $(p<0.0001)$. Solution Ca concentrations in FM and FLM were $91 \mathrm{mg} \mathrm{L}^{-1}$ at $1 \mathrm{~d}$ after experiment initiation (DAI), over twice as high as concentrations in FL (Fig. 1). Thereafter, Ca concentrations in FM and FLM sharply decreased to a minimum concentration of $5 \mathrm{mg} \mathrm{L}^{-1}$ (23 DAI) or $15 \mathrm{mg} \mathrm{L}^{-1}$ (15 DAI), respectively. The relatively high initial $\mathrm{Ca}$ concentrations in FM and FLM compared to FL suggests that the dolomite component in the micronutrient fertilizer was highly soluble relative to the separately added dolomite amendment in FL and FLM. Rapid dissolution of the dolomite component in the micronutrient fertilizer is likely partially attributed to the acidic $\mathrm{pH}$ of the FM substrate at 1 to $9 \mathrm{DAI}(\mathrm{pH}=3.8$ to 4.3$)$ relative to that in $\mathrm{FL}\left(\mathrm{pH}=6.4\right.$ to 7.3 ; Fig. 1). Solubility of $\mathrm{CaMg}\left(\mathrm{CO}_{3}\right)_{2}$ is well known to increase with decreasing pH (Gautelier et al., 1999; Lindsay, 1979). Calcium concentrations in FLM were equivalent to those in FL from 15 to $48 \mathrm{DAI}$, whereas Ca concentrations in FM were consistently 6 to $11 \mathrm{mg} \mathrm{L}^{-1}$ lower than those in FL during this period. From 31 to $48 \mathrm{DAI}$, Ca concentrations in FM were equivalent to those in F. These data suggest that dolomite was the primary source of soluble Ca in FLM after 15 DAI or receiving $\sim 39 \mathrm{~cm}$ total irrigation. The increase in Ca concentration in F between 23 and 41 DAI corresponded with increased leachate $\mathrm{K}$ concentrations due to $\mathrm{CRF}$ release (data not shown). Displacement of $\mathrm{Ca}$ from exchange sites in pine bark by $\mathrm{K}$ has been reported and may explain the increasing leachate Ca concentration in F between 23 and 48 DAI (Hoskins et al.,
Ca
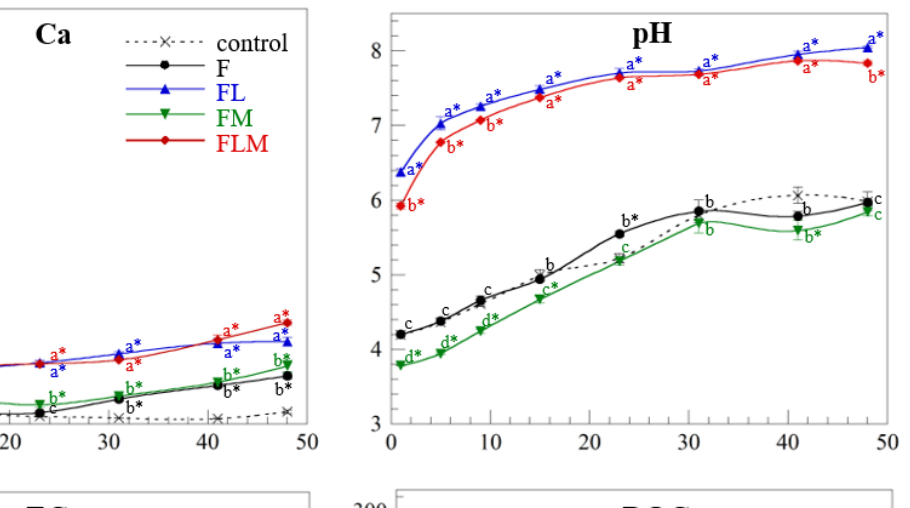

$30 \quad 40$
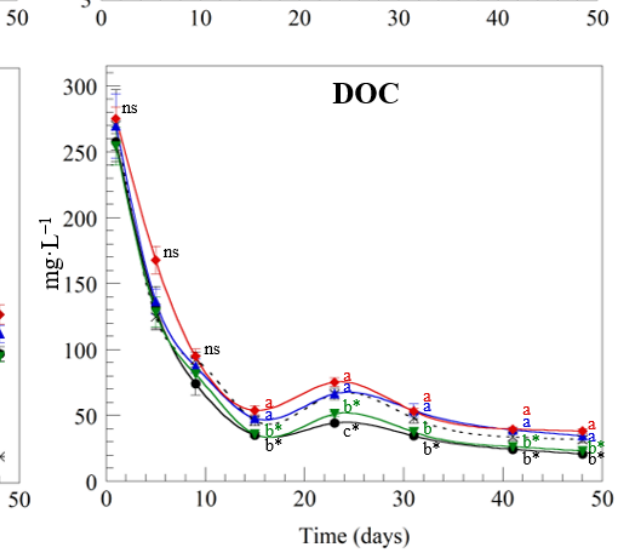

Fig. 1. Effect of substrate amendments on Ca concentration, $\mathrm{pH}$, electrical conductivity (EC), and dissolved organic carbon (DOC) concentration in leachate over time of daily-irrigated pine bark columns containing $4.75 \mathrm{~kg} \mathrm{~m}^{-3}$ controlled-release fertilizer (F;19N-2.6P-10K). Substrate treatments consisted of $4.15 \mathrm{~kg} \mathrm{~m}^{-3}$ dolomite (FL), $0.89 \mathrm{~kg} \mathrm{~m}^{-3}$ micronutrient fertilizer (FM), the combination amendments (control). Different vertically aligned letters next to means indicate significant difference among substrate treatments (F, FL, FM, and FLM) within each sampling date via Tukey's HSD $(p<0.05)$,

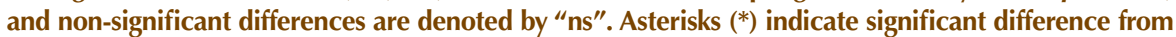
the control using Dunnett's test $(p<0.05)$. Vertical bars represent SE of the mean.

2014). Magnesium concentrations in leachate (data not shown) had a strong, positive correlation with $\mathrm{Ca}$ for all substrate treatments $(r \geq 0.940)$ due to the coinciding presence of $\mathrm{Mg}$ in all sources of $\mathrm{Ca}$ (e.g., dolomite, irrigation water, pine bark).

\section{Iron}

Iron concentrations were affected by a fraction $\times$ substrate $\times$ time interaction $(p<0.0001$; Table 1). Among substrates, the highest dissolved Fe concentrations were in FM at 1 to $15 \mathrm{DAI}$ and in the control from 31 to $48 \mathrm{DAI}$ (Table 2). The relatively high dissolved Fe concentrations in FM at 1 to 15 DAI were a result of the Fe supplied by the micronutrient fertilizer in combination with low substrate $\mathrm{pH}$ (i.e., 3.8 to 4.7) which maintained Fe in solution. At 31 to $48 \mathrm{DAI}$, higher dissolved Fe concentrations in the control compared to all other treatments may have been a result of lower OP concentrations in the control to precipitate or coprecipitate with dissolved Fe (Table 3). The observed relatively low dissolved Fe concentrations in substrates containing the micronutrient fertilizer at 31 to 48 DAI corresponds with Wright and Hinesley (1991) who reported that granular micronutrient fertilizer amendment rates of up to $1.5 \mathrm{~kg} \mathrm{~m}^{-3}$ in a pine bark substrate had no effect on water-extractable Fe concentrations when measured $60 \mathrm{~d}$ after potting Juniperus viginiana $\mathrm{L}$. The authors also reported that liming the substrate reduced $\mathrm{Fe}$ in water extracts, regardless 
Table 1. Degrees of freedom (df), $F$ values, and $p$ values for three-way analysis of variance (ANOVA) to determine significant effects of substrate treatment, fraction, time, and their interactions on $\mathrm{P}$ and Fe concentrations in leachate of irrigated pine bark. Two analyses were performed for $P$, one included total $P$ fractions (particulate $P$ [PP] and total dissolved $P$ [TDP]), and the other included dissolved $P$ fractions (orthophosphate-P $[\mathrm{OP}]$ and non-orthophosphate dissolved $\mathrm{P}$ [NODP]). Fractions in Fe analysis included particulate Fe and dissolved Fe.

\begin{tabular}{|c|c|c|c|c|c|c|c|}
\hline \multirow[b]{2}{*}{ ANOVA source } & \multirow[b]{2}{*}{ df } & \multicolumn{2}{|c|}{ Total $\mathbf{P}$ fractions } & \multicolumn{2}{|c|}{ Dissolved P fractions } & \multicolumn{2}{|c|}{ Fe fractions } \\
\hline & & $F$ value & $p$ value & $F$ value & $p$ value & $F$ value & $p$ value \\
\hline \multicolumn{8}{|l|}{ 3-way ANOVA } \\
\hline Time $(\mathrm{T})$ & 7 & 273.4 & $<0.0001$ & 309.8 & $<0.0001$ & 735.5 & $<0.0001$ \\
\hline Substrate (Sub)† & 3 & 9.9 & $<0.0001$ & 28.9 & $<0.0001$ & 93.3 & $<0.0001$ \\
\hline Fraction (Frac) & 1 & 355.2 & $<0.0001$ & 34.9 & $<0.0001$ & 1032.4 & $<0.0001$ \\
\hline $\mathrm{T} \times \mathrm{Sub}$ & 21 & 5.8 & $<0.0001$ & 6.5 & $<0.0001$ & 13.0 & $<0.0001$ \\
\hline $\mathrm{T} \times$ Frac & 7 & 45.5 & $<0.0001$ & 45.8 & $<0.0001$ & 74.4 & $<0.0001$ \\
\hline Sub $\times$ Frac & 3 & 11.6 & $<0.0001$ & 14.2 & $<0.0001$ & 26.1 & $<0.0001$ \\
\hline $\mathrm{T} \times \mathrm{Sub} \times$ Frac & 21 & 3.0 & 0.0002 & 4.3 & $<0.0001$ & 16.6 & $<0.0001$ \\
\hline \multicolumn{8}{|l|}{ Simple interactionsł } \\
\hline \multicolumn{8}{|l|}{$\mathrm{T} \times$ Sub (in each Frac) } \\
\hline PP, NODP, particulate Fe & 21 & 4.8 & $<0.0001$ & 1.2 & 0.3186 & 13.0 & $<0.0001$ \\
\hline TDP, OP-P, dissolved Fe & 21 & 4.3 & $<0.0001$ & 10.7 & $<0.0001$ & 11.8 & $<0.0001$ \\
\hline \multicolumn{8}{|l|}{$\mathrm{T} \times$ Frac (in each Sub) } \\
\hline $\mathrm{F}$ & 7 & 34.8 & $<0.0001$ & 10.1 & 0.0026 & 58.9 & $<0.0001$ \\
\hline $\mathrm{FL}$ & 7 & 14.0 & $<0.0001$ & 3.8 & 0.0480 & 46.7 & $<0.0001$ \\
\hline FM & 7 & 3.3 & 0.0370 & 10.9 & 0.0032 & 12.6 & $<0.0001$ \\
\hline FLM & 7 & 18.0 & $<0.0001$ & 60.9 & $<0.0001$ & 36.8 & $<0.0001$ \\
\hline \multicolumn{8}{|l|}{ Sub $\times$ Frac $($ at each $T)$} \\
\hline 1 & 3 & 6.5 & 0.0025 & 27.5 & $<0.0001$ & 120.4 & $<0.0001$ \\
\hline 5 & 3 & 5.7 & 0.0042 & 18.6 & $<0.0001$ & 37.3 & $<0.0001$ \\
\hline 9 & 3 & 2.1 & 0.1336 & 3.5 & 0.0296 & 5.0 & 0.0081 \\
\hline 15 & 3 & 2.5 & 0.0812 & 4.4 & 0.0130 & 1.2 & 0.3340 \\
\hline 23 & 3 & 3.0 & 0.0496 & 0.2 & 0.8897 & 2.0 & 0.1481 \\
\hline 31 & 3 & 15.3 & $<0.0001$ & 4.0 & 0.0193 & 2.8 & 0.0596 \\
\hline 41 & 3 & 8.7 & 0.0004 & 3.3 & 0.0369 & 1.1 & 0.3795 \\
\hline 48 & 3 & 8.6 & 0.0005 & 2.6 & 0.0740 & 1.0 & 0.4272 \\
\hline
\end{tabular}

+ Four substrate amendment treatments each contained $4.75 \mathrm{~kg} \mathrm{~m}^{-3}$ controlled-release fertilizer (CRF; $\left.19 \mathrm{~N}-2.6 \mathrm{P}-10 \mathrm{~K}\right)$ and either $4.15 \mathrm{~kg} \mathrm{~m}{ }^{-3}$ dolomitic limestone (FL), $0.89 \mathrm{~kg} \mathrm{~m}^{-3}$ micronutrient fertilizer (FM), both amendments (FLM), or no amendments (F).

\# Since 3-way interactions were significant, 2-way interactions were analyzed at each level of the third factor (i.e., simple interactions).

of the presence of micronutrient fertilizer. Similarly, Abreu et al. (2006) found that water-extractable Fe concentrations were similar in limed pine bark with and without added micronutrients. In a study that used the same micronutrient fertilizer product used in the current study, Handreck (1989) found that $<1 \%$ of $111 \mathrm{mg}$ Fe added to pine bark was recovered in effluent after $50 \mathrm{~d}$ of daily leaching, most of which was found within the first $6 \mathrm{~d}$. Our results agree with these studies in that liming agents and the subsequent increase in $\mathrm{pH}$ reduces Fe solubility in pine bark.

Particulate-Fe concentrations were highest in the control, F, and FL at 1 DAI and in the control and F at 5 DAI (Table 2). From 9 to $48 \mathrm{DAI}$, substrates had a similar effect on particulate Fe as that described for dissolved Fe. At 1 DAI, the lower particulate Fe concentrations in substrates containing micronutrient fertilizer suggests Fe-containing particles may have flocculated due to relatively high solution EC (Jirsa et al., 2013; Sholkovitz, 1976). Similarly, at 31 to $48 \mathrm{DAI}$, low particulate Fe in fertilized substrates relative to the control corresponded with higher EC.

\section{pH}

Leachate $\mathrm{pH}$ was affected by a substrate $\times$ time interaction $(p<0.0001)$, which is explained by the more rapid initial increase in $\mathrm{pH}$ of substrates containing dolomite compared to those without dolomite (Fig. 1). Leachate $\mathrm{pH}$ in all five substrate treatments increased by $\sim 1.8 \pm 0.07$ units over $48 \mathrm{~d}$. Substrates containing dolomite reached $\mathrm{pH}$ values of $\sim 8.0$ by $41 \mathrm{DAI}$, which are higher than values reported in studies in which a comparable dolomite rate was used. In a comprehensive review on the effects of dolomite additions in pine bark, Altland and Jeong (2016) proposed that dolomite can increase substrate $\mathrm{pH}$ up to $\sim 6.5$ before $\mathrm{pH}$ limits its solubility and concomitant effects on $\mathrm{pH}$. A possible explanation for the observed high $\mathrm{pH}$ values is that the inherent acidity of the pine bark was leached due to daily irrigation with $\sim 2.6 \mathrm{~cm}$ water; however, this amount of water can be applied in a conventional nursery setting via daily irrigation and rainfall. Assuming the inherent acidity of the pine bark was reduced, substrate $\mathrm{pH}$ would have been more responsive to the lime reaction and the $\mathrm{pH}$ of the irrigation water, which increased from 6.9 to 7.8 over the course of the experiment (data not shown). Leachate $\mathrm{pH}$ values of the control and $\mathrm{F}$ 
were generally equivalent; hence, the CRF had a minor effect on leachate $\mathrm{pH}$. From 1 to $23 \mathrm{DAI}, \mathrm{pH}$ values of FM were $0.38 \pm$ 0.03 units lower than those of F. Similarly, $\mathrm{pH}$ of FLM was 0.2 to 0.5 units lower than that of FL at 1 to $9 \mathrm{DAI}$, suggesting the micronutrient fertilizer acidified the substrate. Wright et al. (1999) observed a similar magnitude decrease in $\mathrm{pH}(0.5$ units) when pine bark was amended with micronutrient fertilizer.

\section{Electrical Conductivity}

Leachate EC was affected by a substrate $\times$ time interaction $(p<0.0001)$ due to the more rapid decrease in EC in substrates containing micronutrient fertilizer compared to those with no micronutrient fertilizer during the first 9 DAI. Electrical conductivity values in $\mathrm{F}$ were the same as those in the control at 1,5 , and 9 DAI during which EC values in both substrates decreased from 0.51 to $0.21 \mathrm{mS} \mathrm{cm}^{-1}$. At $15 \mathrm{DAI}, \mathrm{EC}$ values in $\mathrm{F}$ were $29 \%$ higher than those in the control, and from 15 to $48 \mathrm{DAI}, \mathrm{EC}$ values in $\mathrm{F}$ and the control increased $178 \%$ and decreased $29 \%$, respectively. Accordingly, these data suggest that the fertilizer began releasing salts between 9 and 15 DAI. Electrical conductivity values in FM and FLM were equivalent at 1 and 5 DAI during which EC values in these two treatments decreased $~ 50 \%$. From 1 to $23 \mathrm{DAI}, \mathrm{EC}$ values in FL were between 27 and 89\% higher than those in F. Observed higher EC values in FL compared to F were likely due to dolomite dissolution and subsequent presence of $\mathrm{Mg}$ and $\mathrm{Ca}$ in leachate.

\section{Dissolved Organic Carbon}

Dissolved organic carbon was influenced by a substrate $\times$ time interaction ( $p=0.0043$; Fig. 1$)$. The DOC concentrations were the same across treatments at 1,5 , and 9 DAI during which DOC decreased from $\sim 265$ to $\sim 85 \mathrm{mg} \mathrm{L}^{-1}$. Thereafter, DOC concentrations increased by $\sim 10$ to $20 \mathrm{mg} \mathrm{L}^{-1}$ between 15 and 23 DAI then decreased for the remainder of the study. A substrate effect on DOC concentrations was first apparent at $15 \mathrm{DAI}$, during which the control or substrates containing dolomite had highest DOC. This relationship among treatments remained the same until experiment termination, with DOC concentrations 35 to $45 \%$ higher in limed treatments or the control compared to $\mathrm{F}$ or FM. The higher DOC concentrations of limed treatments at 15 to 48 DAI was likely due to the relatively high $\mathrm{pH}$ and thus greater solubility of humic acids in these treatments (Kipton and Town, 1992). However, DOC concentrations in the control were higher than those in $\mathrm{F}$ and $\mathrm{FM}$ despite having similar $\mathrm{pH}$ values. Higher DOC concentrations of the control compared to the non-limed treatments may be due to the substantially lower EC values of the control and corresponding degree of DOC flocculation. According to findings by Tiemeyer et al. (2017), pH has less impact on DOC when EC values are low (i.e., $94 \mu \mathrm{S} \mathrm{cm}^{-1}$ ). Hence, the low EC values in the control between 15 and 48 DAI may have nullified the effect of relatively low $\mathrm{pH}$ values on DOC.

\section{Phosphorus}

The time $\times$ substrate $\times$ treatment interaction was significant for both P-fraction analyses, that is, PP versus TDP and OP versus NODP $(p<0.0001$; Table 1$)$. For the PP versus TDP analysis, all simple interactions were significant $(p<0.05)$ except the substrate $\times$ fraction interaction at 9 and $15 \mathrm{DAI}(p \geq 0.05)$.

Particulate $P$ concentrations were affected by substrate treatments at all sampling dates except 9, 15, and 41 DAI (Table 3). In all substrates, PP concentrations were highest at $1 \mathrm{DAI}$, decreased rapidly between 1 and $5 \mathrm{DAI}$, then remained $<1.5 \mathrm{mg} \mathrm{L}^{-1}$. At 1 DAI, highest PP was found in the control, F, and FL, whereas at 5 DAI, PP concentrations were highest in the control, F, and FM. A portion of the PP present at 1 and 5 DAI may be attributed to $\mathrm{MnHPO}_{4}$ and $\mathrm{Ca}_{5}\left(\mathrm{PO}_{4}\right)_{3}(\mathrm{OH})$ precipitates, as both compounds were saturated with respect to their solid phases in all substrates during this period (Table 4). When pooled across all substrates and sampling dates, PP had a strong, positive correlation with particulate $\mathrm{Fe}(r=0.94)$ and DOC $(r=0.86)$. These parallel changes in $\mathrm{PP}$, particulate $\mathrm{Fe}$, and DOC suggest possible formation of humic-Fe- $\mathrm{PO}_{4}$ precipitates (Petrovic and Kastelan-Macan, 1996). However, further investigation is needed to confirm the existence of humic-Fe- $\mathrm{PO}_{4}$ precipitates in pine bark substrates. At 
Table 3. Effect of substrate amendments $(n=4)$ on $P$ concentrations $\left(\mathrm{mg} \mathrm{L}^{-1} \mathrm{P}\right)$ and distribution of $\mathrm{P}$ concentration across fractions over time in leachate of daily-irrigated pine bark columns containing $4.75 \mathrm{~kg} \mathrm{~m}^{-3}$ controlled-release fertilizer $(\mathrm{F} ; 19 \mathrm{~N}-2.6 \mathrm{P}-10 \mathrm{~K})$. Substrate treatments consisted of $4.15 \mathrm{~kg} \mathrm{~m}^{-3}$ dolomite (FL), $0.89 \mathrm{~kg} \mathrm{~m}^{-3}$ micronutrient fertilizer (FM), the combination of dolomite and micronutrient fertilizer (FLM), or pine bark with no fertilizer or amendments (control). Total P (TP) was fractioned into total dissolved P (TDP; $<0.45 \mu \mathrm{m})$ and particulate P (PP; TP - TDP), and TDP was further divided into orthophosphate-P (OP) and non-orthophosphate dissolved P (NODP; TDP - OP) for separate statistical analysis.

\begin{tabular}{|c|c|c|c|c|c|c|c|}
\hline Time, days & Substrate & PP & TDP & $p$ valuet & NODP & OP & $p$ value \\
\hline \multirow[t]{6}{*}{1} & Control & 6.34 & 8.60 & 0.0235 & 4.08 & 4.52 & 0.3479 \\
\hline & $\mathrm{F}$ & $6.67 \mathrm{a} \S$ & $8.86 \mathrm{a}$ & 0.0097 & 4.28 & $4.58 \mathrm{a}$ & 0.3554 \\
\hline & $\mathrm{FL}$ & $5.94 \mathrm{ab}$ & $6.57 b^{*}$ & 0.2384 & 3.54 & $3.03 b^{*}$ & 0.1264 \\
\hline & FM & $3.07 c^{*}$ & $6.24 b^{*}$ & 0.0072 & 4.29 & $1.96 c^{*}$ & 0.0053 \\
\hline & FLM & $4.04 b^{*}$ & $4.48 c^{*}$ & 0.2400 & 3.45 & $1.03 d^{*}$ & $<0.0001$ \\
\hline & $p$ value & 0.0003 & $<0.0001$ & & 0.0911 & $<0.0001$ & \\
\hline \multirow[t]{6}{*}{5} & Control & 0.97 & 7.53 & $<0.0001$ & 3.57 & 3.97 & 0.0486 \\
\hline & $\mathrm{F}$ & $1.28 \mathrm{a}$ & $8.06 \mathrm{a}$ & $<0.0001$ & $3.65 \mathrm{a}$ & $4.42 \mathrm{a}$ & 0.0810 \\
\hline & $\mathrm{FL}$ & $0.56 \mathrm{~b}$ & $5.46 b^{*}$ & $<0.0001$ & $2.44 b^{*}$ & $3.02 b^{*}$ & 0.0662 \\
\hline & FM & $1.04 \mathrm{ab}$ & $4.80 b^{*}$ & 0.0003 & $2.95 a b$ & $1.85 \mathrm{c}^{*}$ & 0.0240 \\
\hline & FLM & $0.45 \mathrm{~b}$ & $3.30 \mathrm{c}^{*}$ & $<0.0001$ & $2.38 b^{*}$ & $0.92 d^{*}$ & $<0.0001$ \\
\hline & $p$ value & 0.0125 & $<0.0001$ & & 0.0131 & $<0.0001$ & \\
\hline \multirow[t]{6}{*}{9} & Control & 1.21 & 5.15 & $<0.0001$ & 1.68 & 3.47 & 0.0002 \\
\hline & $\mathrm{F}$ & 1.28 & $4.20 \mathrm{a}$ & 0.0004 & 1.31 & $2.89 \mathrm{a}$ & 0.0043 \\
\hline & $\mathrm{FL}$ & 1.15 & $3.33 \mathrm{a}^{*}$ & 0.0023 & $1.10 *$ & $2.23 \mathrm{a}^{*}$ & 0.0156 \\
\hline & FM & 1.37 & $3.24 \mathrm{a}^{*}$ & 0.0021 & 1.30 & $1.94 \mathrm{ab}^{*}$ & 0.1034 \\
\hline & FLM & 0.82 & $1.98 b^{*}$ & 0.0025 & $0.90 *$ & $1.08 b^{*}$ & 0.0548 \\
\hline & $p$ value & 0.0895 & 0.0026 & & 0.1631 & 0.0028 & \\
\hline \multirow[t]{6}{*}{15} & Control & 0.25 & 2.17 & 0.0008 & 0.86 & 1.31 & 0.5276 \\
\hline & $\mathrm{F}$ & 0.53 & $1.15 *$ & 0.0002 & 0.32 & 0.84 & 0.2086 \\
\hline & $\mathrm{FL}$ & 0.58 & $1.06 *$ & 0.1272 & 0.63 & 0.43 & 0.4733 \\
\hline & FM & 0.43 & 1.64 & 0.0014 & 0.37 & 1.27 & 0.1596 \\
\hline & FLM & 0.65 & $0.91 *$ & 0.2607 & 0.84 & 0.07 & $<0.0001$ \\
\hline & $p$ value & 0.7876 & 0.0513 & & 0.2437 & 0.0750 & \\
\hline \multirow[t]{6}{*}{23} & Control & 0.26 & 1.20 & $<0.0001$ & 0.90 & 0.30 & 0.1024 \\
\hline & $\mathrm{F}$ & $0.09 \mathrm{~b}$ & 0.60 & 0.0017 & 0.20 & 0.40 & 0.1732 \\
\hline & $\mathrm{FL}$ & $0.20 \mathrm{ab}$ & 0.69 & 0.1923 & 0.37 & 0.32 & 0.9330 \\
\hline & FM & $0.18 \mathrm{ab}$ & 1.11 & 0.0011 & 0.45 & 0.66 & 0.5723 \\
\hline & FLM & $0.39 \mathrm{a}$ & 0.50 & 0.2906 & 0.21 & 0.29 & 0.5760 \\
\hline & $p$ value & 0.0279 & 0.1952 & & 0.8770 & 0.4832 & \\
\hline \multirow[t]{6}{*}{31} & Control & 0.27 & 0.56 & 0.0123 & 0.26 & 0.30 & 0.7567 \\
\hline & $\mathrm{F}$ & $0.06 b^{*}$ & $0.99 \mathrm{ab}$ & 0.0008 & $0.17 \mathrm{ab}$ & $0.82 \mathrm{a}^{*}$ & 0.0086 \\
\hline & $\mathrm{FL}$ & $0.22 \mathrm{a}$ & $0.27 \mathrm{c}$ & 0.7162 & $0.07 \mathrm{~b}$ & $0.20 \mathrm{~b}$ & 0.1191 \\
\hline & FM & $0.07 b^{*}$ & $1.25 \mathrm{a}^{*}$ & 0.0002 & $0.23 \mathrm{a}$ & $1.02 \mathrm{a}^{*}$ & 0.0036 \\
\hline & FLM & $0.28 \mathrm{a}$ & $0.53 \mathrm{bc}$ & 0.0923 & $0.10 \mathrm{ab}$ & $0.43 \mathrm{ab}$ & 0.0117 \\
\hline & $p$ value & 0.0025 & 0.0018 & & 0.0453 & 0.0036 & \\
\hline \multirow[t]{6}{*}{41} & Control & 0.20 & 0.30 & 0.0740 & 0.09 & 0.21 & 0.0291 \\
\hline & $\mathrm{F}$ & $0.08 *$ & $1.77 \mathrm{a}^{*}$ & $<0.0001$ & $0.27 *$ & $1.50 a^{*}$ & 0.0002 \\
\hline & $\mathrm{FL}$ & 0.13 & 0.81 bc* & 0.0003 & 0.12 & $0.69 c^{*}$ & 0.0016 \\
\hline & FM & 0.10 & $1.57 \mathrm{ab}^{*}$ & $<0.0001$ & 0.22 & $1.35 \mathrm{ab}^{*}$ & 0.0003 \\
\hline & FLM & 0.19 & $0.83 \mathrm{c}^{*}$ & 0.0089 & 0.13 & $0.70 \mathrm{bc}^{*}$ & 0.0123 \\
\hline & $p$ value & 0.1781 & 0.0046 & & 0.0910 & 0.0050 & \\
\hline \multirow[t]{6}{*}{48} & Control & 0.34 & 0.23 & 0.8684 & 0.08 & 0.15 & 0.0921 \\
\hline & $\mathrm{F}$ & $0.16 \mathrm{bc}$ & $2.47 a^{*}$ & $<0.0001$ & $0.36 *$ & $2.11 \mathrm{a}^{*}$ & $<0.0001$ \\
\hline & $\mathrm{FL}$ & $0.36 \mathrm{ab}$ & $1.20 \mathrm{~b}^{*}$ & 0.2441 & 0.14 & $1.06 b^{*}$ & 0.0011 \\
\hline & FM & $0.09 \mathrm{c}$ & $1.98 \mathrm{ab}^{*}$ & 0.0003 & 0.32 & $1.66 \mathrm{ab}^{*}$ & 0.0032 \\
\hline & FLM & $0.40 \mathrm{a}$ & $1.17 b^{*}$ & 0.0133 & 0.23 & $0.94 b^{*}$ & 0.0101 \\
\hline & $p$ value & 0.0022 & 0.0138 & & 0.2534 & 0.0069 & \\
\hline
\end{tabular}

* Significantly different from control according to Dunnett's test at the 0.05 probability level.

$+p$ values $<0.05$ indicate TDP and PP concentrations are significantly different.

$\neq p$ values $<0.05$ indicate OP and NODP concentrations are significantly different.

$\S$ Within columns for each sampling date, means followed by the same letter are not significantly different according to Tukey's HSD (0.05). 
31 and 48 DAI, highest PP concentrations were in the control and substrates containing dolomite (Table 3). Relatively high PP concentrations in substrates containing dolomite at 31 and $48 \mathrm{DAI}$, during which $\mathrm{pH}$ values were favorable for $\mathrm{Ca}-\mathrm{PO}_{4}$ precipitation, may have been due to formation of $\mathrm{Ca}-\mathrm{PO}_{4}$ precipitates. Formation of $\mathrm{Ca}-\mathrm{PO}_{4}$ precipitates is supported by data from Visual MINTEQ modeling which indicated leachate solutions from FL and FLM were saturated with respect to the $\mathrm{Ca}_{5}\left(\mathrm{PO}_{4}\right)_{3}(\mathrm{OH})$ solid phase at 41 and $48 \mathrm{DAI}$ (Table 4). The solid phase of $\mathrm{Ca}_{3}\left(\mathrm{PO}_{4}\right)_{2}$ was also saturated in FL and FLM at 48 DAI; however, saturation index values of $\mathrm{Ca}_{3}\left(\mathrm{PO}_{4}\right)_{2}$ were low relative to those of $\mathrm{Ca}_{5}\left(\mathrm{PO}_{4}\right)_{3}(\mathrm{OH})$. Kinetics, metastable fast formers, and the presence of DOC can limit precipitation and thus interpretation of this simulation output. Relatively high DOC concentrations, such as those observed in the current study make interpretation of $\mathrm{Ca}-\mathrm{PO}_{4}$ precipitate formation particularly challenging, as DOC has been shown to impede nucleation of $\mathrm{Ca}-\mathrm{PO}_{4}$ precipitates (Song et al., 2006).

Total dissolved $\mathrm{P}$ concentrations in $\mathrm{F}$ were similar to those in the control until 41 DAI (Table 3), suggesting indigenous P in the pine bark was the primary source of TDP until the CRF began releasing $P$ between 31 and 41 DAI. Delayed P release from CRF is commonly reported in nursery crop production research (Broschat, 2005; Broschat and Moore, 2007; Du et al., 2006; Newman et al., 2006). Total dissolved P concentrations in the control decreased 75\% between 1 and 15 DAI. Yeager and Wright (1982) also reported relatively high amounts of soluble $\mathrm{P}$ in a pine bark substrate. At 1, 5, 41, and 48 DAI, TDP concentrations were lower in FL and FLM than in F. Total dissolved P concentrations were lowest in FLM at 1 and 5 DAI, whereas at 41 and 48 DAI, FL and FLM had equivalent TDP concentrations. The FM substrate reduced TDP at 1 and 5 DAI in similar amounts as FL; however, TDP concentrations in FM were the same as those in $\mathrm{F}$ at 9 to 48 DAI. These data suggest that while micronutrient fertilizer reduced TDP concentrations by 30 and $40 \%$ at 1 and 5 DAI, respectively, this effect was short-lived. The greater effectiveness of FLM at reducing TDP concentrations at the beginning of the study, relative to the end of the study, can therefore be explained by initial TDP reductions by the micronutrient fertilizer. Decreases in TDP by dolomite and the micronutrient fertilizer did not necessarily correspond with a proportional increase in PP, suggesting dolomite and micronutrient fertilizer amendments improved total $P$ retention in the substrate. To further investigate the effect of substrate amendments on $\mathrm{P}$ retention in pine bark, an additional repeated measures ANOVA was performed on total P (TDP + PP; data not shown). Assessment of total $\mathrm{P}$ concentrations revealed a similar response to substrate treatments as was described for TDP. The effect of substrate on TP was significant at $1 \mathrm{DAI}(p<0.0001), 5 \mathrm{DAI}(p<$ $0.0001), 9 \mathrm{DAI}(p=0.0004), 31 \mathrm{DAI}(p=0.0050)$, and $41 \mathrm{DAI}$ ( $p=0.0076$ ). The FLM substrate reduced TP concentrations, on average, by $51 \%$ at 1,5 , and $9 \mathrm{DAI}$ and by $45 \%$ at $41 \mathrm{DAI}$. The FL substrate reduced TP concentrations by 19 and $36 \%$ at 1 and 5 DAI, respectively, and by $\sim 52 \%$ at 31 and 41 DAI. In contrast,
Table 4. Saturation indices calculated by Visual MINTEQ for P species aturated with respect to the solid phase (positive values) in leachate at 1, 5, 40, and $48 \mathrm{~d}$ after experiment initiation of irrigated pine bark columns containing no amendments (control) or $4.75 \mathrm{~kg} \mathrm{~m}^{-3}$ of $19 \mathrm{~N}-2.6 \mathrm{P}-10 \mathrm{~K}$ controlled-release fertilizer $(\mathrm{F})$ with $4.15 \mathrm{~kg} \mathrm{~m}^{-3}$ dolomite (FL), $0.89 \mathrm{~kg} \mathrm{~m}^{-3}$ micronutrient fertilizer (FM), or the combination of dolomite and micronutrient fertilizer (FLM).

\begin{tabular}{llrrrr} 
& & \multicolumn{4}{c}{ Time, days after initiation } \\
\cline { 3 - 6 } Substrate & \multicolumn{1}{c}{ Species } & $\mathbf{1}$ & $\mathbf{5}$ & $\mathbf{4 1}$ & $\mathbf{4 8}$ \\
\hline Control & $\mathrm{MnHPO}_{4}$ & 1.32 & 0.90 & -1.09 & -0.87 \\
F & $\mathrm{MnHPO}_{4}$ & 1.32 & 0.98 & 2.21 & 2.41 \\
$\mathrm{FL}$ & $\mathrm{Ca}_{5}\left(\mathrm{PO}_{4}\right)_{3}(\mathrm{OH})$ & 2.01 & 4.09 & 7.00 & 7.70 \\
& $\mathrm{MnHPO}_{4}$ & 2.95 & 2.97 & 2.11 & 2.09 \\
& $\mathrm{Ca}_{3}(\mathrm{PO} 4)_{2}($ beta) & -2.43 & -1.37 & -0.12 & 0.30 \\
FM & $\mathrm{MnHPO}_{4}$ & 1.94 & 1.65 & 2.22 & 2.61 \\
FLM & $\mathrm{Ca}_{5}\left(\mathrm{PO}_{4}\right)_{3}(\mathrm{OH})$ & 0.23 & 3.51 & 6.59 & 7.26 \\
& $\mathrm{MnHPO}_{4}$ & 3.42 & 3.53 & 2.53 & 2.50 \\
& $\mathrm{Ca}_{3}\left(\mathrm{PO}_{4}\right)_{2}($ beta $)$ & -3.44 & -1.70 & -0.33 & 0.10 \\
\hline
\end{tabular}

effects of FM on TP concentrations were apparent only at 1 and 5 DAI, during which TP concentrations were $\sim 36 \%$ lower than those in F. Thus, TP retention in FLM was initially controlled by the combination of dolomite and micronutrient fertilizer and later by dolomite only. The short-term effect of micronutrient fertilizer on P sorption may be related to its solubility. The rapid decrease in $\mathrm{Ca}$ and $\mathrm{Mg}$ to concentrations equivalent to or nearly equivalent to those in F by 23 DAI suggests that most of the dolomite in the micronutrient fertilizer had dissolved by 31 DAI. The component in the micronutrient fertilizer controlling $\mathrm{P}$ sorption is unclear however since the dolomite, $\mathrm{Mn}$, and Fe constituents in the micronutrient fertilizer may have had a role. Spectroscopic evidence has shown that retention of $\mathrm{P}$ by dolomite at relatively low $\mathrm{P}$ concentrations (i.e., $<2 \mathrm{mg} \mathrm{L}^{-1}$ ) is primarily due to $\mathrm{PO}_{4}$ sorption to $\mathrm{Ca}$ and $\mathrm{Mg}$ sorption complexes (Xu et al., 2014).

The substrate $\times$ time simple interaction was significant for OP $(p<0.0001)$, but not for NODP $(p=0.3186$; Table 1$)$. The substrate $\times$ time interaction for $\mathrm{OP}$ was due to the decreasing effect of micronutrient fertilizer on OP concentrations over time. At 1 and 5 DAI, OP concentrations were lower in FM than in FL, and lowest concentrations were in FLM. In contrast, at 31 to 48 DAI, $\mathrm{OP}$ concentrations in FM were the same as those in F, and lowest concentrations were found in FL to FLM. Hence, the response of OP to substrate amendments was similar to that of TDP; however, percentage reductions in $\mathrm{OP}$ in response to amendments were generally greater than those of TDP. Orthophosphate-P was 23 to $55 \%$ of TDP in all substrates at 1 and 5 DAI, with generally lower proportions found in FLM. Thirty-one to $48 \mathrm{DAI}$, when the CRF was releasing P, OP contributed 74 to $86 \%$ of TDP in fertilized treatments. The relatively high initial NODP concentrations (i.e., $3.9 \mathrm{~m} \mathrm{~L}^{-1}$ ) decreased until $31 \mathrm{DAI}$, then remained relatively low compared to OP. The NODP fraction may have been associated with dissolved metal-humic complexes (Gerke, 2010). This fate of $\mathrm{P}$ is supported by Visual MINTEQ aqueous speciation output which predicted between $95 \%$ and $99 \%$ of $\mathrm{Fe}$ in solution was associated organic acids (data not shown). In addition, the positive correlation between NODP and DOC $(r=0.90)$ was stronger 
that that between OP and DOC $(r=0.58)$, which supports the possibility of an association between NODP and organic substances. Van Moorleghem et al. (2011) determined that organic Fe colloids present in filtered solutions $(<0.45 \mu \mathrm{m})$ reduced detection of OP by ion chromatography by as much as $51 \%$, whereas TDP (determined via ICP-OES) was unaffected. Additional research is needed to investigate the OP to TDP ratio in pine bark once CRF release increases $\mathrm{OP}$ concentrations to 5 to $10 \mathrm{mg} \mathrm{L}^{-1}$, the current recommended range according to best management practices for container-grown crops (Bilderback et al., 2013a).

\section{CONCLUSIONS}

Results demonstrate that dolomite and micronutrient fertilizer improve $\mathrm{P}$ retention and therefore reduce $\mathrm{P}$ leaching from a pine bark substrate commonly used for production of containerized ornamentals. Compared to the fertilized substrate containing no amendments, the pine bark with dolomite and micronutrient fertilizer reduced OP concentrations by $70 \%$ when averaged across the sampling dates. The effects of micronutrient fertilizer on $\mathrm{P}$ retention were diminished by the ninth irrigation event $(23 \mathrm{~cm})$, whereas dolomite reduced OP leaching throughout the 48-d study. Longevity and extent of P-retention of dolomite when baseline $\mathrm{P}$ concentrations are $>5 \mathrm{mg} \mathrm{L}^{-1}$ need to be further investigated. If dolomite additions to pine bark can reduce $\mathrm{P}$ leaching throughout a growing season, dolomite amendments may be considered a best management practice for containerized crop production.

\section{ACKNOWLEDGMENTS}

The authors thank Julie Brindley, Velva Groover, Anna Birnbaum, and Doug Sturtz for technical assistance, as well as Pacific Organics for donating pine bark for this research. Funding was provided by the Virginia Agricultural Experiment Station and the Hatch Program of the National Institute of Food and Agriculture (including SCRI 201451181-22372), the US Dep. of Agriculture, the Horticultural Research Institute, and the Virginia Nursery and Landscape Association.

\section{REFERENCES}

Abreu, C.A., A.M.C. Furlani, P.R. Furlani, M.F. Abreu, O.C. Bataglia, and A. Paz-Gonzalez. 2006. Quest of water extract analysis of micronutrients in soilless organic substrates. Commun. Soil Sci. Plant Anal. 37:2327-2338. doi:10.1080/00103620600819602

Altland, J.E., and K.Y. Jeong. 2016. Dolomitic lime amendment affects pine bark substrate $\mathrm{pH}$, nutrient availability, and plant growth: A review. Horttechnology 26:565-573. doi:10.21273/HORTTECH03465-16

Alva, A.K., M.E. Sumner, and W.P. Miller. 1991. Relationship between ionic strength and electrical conductivity for soil solutions. Soil Sci. 152:239242. doi:10.1097/00010694-199110000-00001

Argo, W.R., and J.A. Biernbaum. 1996a. The effect of lime, irrigation-water source, and water-soluble fertilizer on root-zone $\mathrm{pH}$, electrical conductivity, and macronutrient management of container root media with impatiens. J. Am. Soc. Hortic. Sci. 121:442-452. doi:10.21273/JASHS.121.3.442

Argo, W.R., and J.A. Biernbaum. 1996b. Availability and persistence of macronutrients from lime and preplant nutrient charge fertilizers in peatbased root media. J. Am. Soc. Hortic. Sci. 121:453-460. doi:10.21273/ JASHS.121.3.453

Bilderback, T., C. Boyer, M. Chappell, G. Fain, D. Fare, C. Gilliam, B.E. Jackson, J. Lea-Cox, A.V. LeBude, A. Niemiera, J. Owen, J. Ruter, K. Tilt, S. Warren, S. White, T. Whitwell, R. Wright, and T. Yeager. 2013a. Best management practices: Guide for producing nursery crops. 3rd ed. Southern Nursery Association, Acworth, GA

Bilderback, T.E., E.D. Riley, B.E. Jackson, H.T. Kraus, W.C. Fonteno, J.S. Owen, Jr., J.E. Altland, and G.B. Fain. 2013b. Strategies for developing sustainable substrates in nursery crop production. Acta Hortic. 1013:43-56. doi:10.17660/ActaHortic.2013.1013.2

Broschat, T.K., and K.K. Moore. 2007. Release rates of ammonium-nitrogen, nitrate-nitrogen, phosphorus, potassium, magnesium, iron, and manganese from seven controlled-release fertilizers. Commun. Soil Sci. Plant Anal. 38:843-850. doi:10.1080/00103620701260946

Broschat, T. 1995. Nitrate, phosphate, and potassium leaching from containergrown plants fertilized by several methods. HortScience 30:74-77. doi:10.21273/HORTSCI.30.1.74

Broschat, T. 2005. Rates of ammonium-nitrogen, nitrate-nitrogen, phosphorus, and potassium from two controlled-release fertilizers under different substrate environments. Horttechnology 15:332-335. doi:10.21273/ HORTTECH.15.2.0332

Bunt, A.C. 1988. Media and mixes for container-grown plants: A manual on the preparation and use of growing media for pot plants. 2nd ed. Unwin Hyman, London. doi:10.1007/978-94-011-7904-1

Carpenter, S.R., N.F. Caraco, D.L. Correll, R.W. Howarth, A.N. Sharpley, and V.H. Smith. 1998. Nonpoint pollution of surface waters with phosphorus and nitrogen. Ecol. Appl. 8:559-568. doi:10.1890/10510761(1998)008[0559:NPOSWW]2.0.CO;2

Cole, J.C., and J.M. Dole. 1997. Temperature and phosphorus source affect phosphorous retention by pine bark- based container medium. HortScience 32:236-240. doi:10.21273/HORTSCI.32.2.236

Dennis, J.H., R.G. Lopez, B.K. Behe, C.R. Hall, C. Yue, and B.L. Campbell. 2010. Sustainable production practices adopted by greenhouse and nursery plant growers. HortScience 45:1232-1237. doi:10.21273/ HORTSCI.45.8.1232

Diara, C., L. Incrocci, G. Incrocci, G. Carmassi, A. Pardossi, P. Marzialetti, P. Cozzi, F. Fibbi, and R. Clemens. 2014. Reduction of nutrient run-off by the use of coated slow-release fertilizers on two container-grown nursery crops. Acta Hortic. 1034:85-91. doi:10.17660/ActaHortic.2014.1034.9

Du, C., J. Zhou, and A. Shaviv. 2006. Release characteristics of nutrients from polymer-coated compound controlled release fertilizers. J. Polym. Environ. 14:223-230. doi:10.1007/s10924-006-0025-4

Fain, G.B., C.H. Gilliam, K.M. Tilt, J.W. Olive, and B. Wallace. 2000. Survey of best management practices in container production nurseries. J. Environ. Hortic. 18:142-144.

Fonteno, W.C., C.T. Hardin, and J.P. Brewster. 1995. Procedures for determining physical properties of horticultural substrates using the NCSU porometer. Horticultural Substrates Laboratory, North Carolina State University, Raleigh, NC. https://projects.ncsu.edu/project/hortsublab/pdf/ porometer_manual.pdf.

Gautelier, M., E.H. Oelkers, and J. Schott. 1999. An experimental study of dolomite dissolution rates as a function of $\mathrm{pH}$ form -0.5 to 5 and temperature from 25 to $80^{\circ} \mathrm{C}$. Chem. Geol. 157:13-26. doi:10.1016/ S0009-2541(98)00193-4

Gerke, J. 2010. Humic (organic matter)-Al(Fe)-phosphate complexes: An underestimated phosphate form in soils and source of plant-available phosphate. Soil Sci. 175:417-425. doi:10.1097/SS.0b013e3181f1b4dd

Gerke, J., and R. Hermann. 1992. Adsorption of orthophosphate to HumicFe-Complexes and to amorphous Fe-Oxide. Z. Pflanzenernähr. Bodenk. 155:233-236. doi:10.1002/jpln.19921550313

Godoy, A., and J.C. Cole. 2000. Phosphorous source affects phosphorous leaching and growth of containerized spirea. HortScience 35:1249-1252. doi:10.21273/HORTSCI.35.7.1249

Gustafsson, J.P. 2013. Visual MINTEQ ver. 3.1. KTH, Stockholm. https:// vminteq.lwr.kth.se/ (Verified 15 Aug. 2019).

Handreck, K.A. 1989. Assessment of iron availability in soilless potting media. Commun. Soil Sci. Plant Anal. 20:1297-1320. doi: $10.1080 / 00103628909368152$

Handreck, K.A. 1991a. Interactions between iron and phosphorus in the nutrition of Banksia ericifolia L.f. var. ericifolia (Proteaceae) in soil-less potting media. Aust. J. Bot. 39:373-384. doi:10.1071/BT9910373

Handreck, K.A. 1991b. Available phosphorus in potting media: Extractants and interpretation of extract data. Commun. Soil Sci. Plant Anal. 22:529-557. doi: $10.1080 / 00103629109368436$

Handreck. K.A. 1992. Iron phosphorous interactions in in the nutrition of seedling macadamia in organic potting media. Australian J. Exp. Hort. 32:773-779.

Handreck, K.A. 1996. Comparison of phosphate-phosphorous and total phosphorus in DTPA extracts for assessing plant-available phosphorus in soilless potting media. Commun. Soil Sci. Plant Anal. 27:2125-2135. doi: $10.1080 / 00103629609369692$ 
Havis, J.R., and J.H. Baker. 1985. Influence of liming rate and phosphorus leaching from a peat-sand medium. J. Environ. Hortic. 3:74-76.

Haynes, J.R. 1982. Leaching losses of nutrients and yield and nutrient uptake by container-grown begonia as affected by lime and fertilizer applications to a peat medium. J. Sci. Food Agric. 33:407-413. doi:10.1002/ jsfa. 2740330503

Hoskins, T.C., J.S. Owen, Jr., and A.X. Niemiera. 2014. Controlled-release fertilizer placement affects the leaching pattern of nutrients from nursery containers during irrigation. HortScience 49:1341-1345. doi:10.21273/ HORTSCI.49.10.1341

Jirsa, F., E. Neubauer, R. Kittinger, T. Hofmann, R. Krachler, F. Kammer, and B.K. Keppler. 2013. Natural organic matter and iron export from the Tanner Moor, Austria. Limnologica 43:239-244.

Johnson, N.L. 1949. Systems of frequency curves generated by methods of translation. Biometrika 36:149-176. doi:10.1093/biomet/36.1-2.149

Karaca, S., A. Gürses, M. Edjer, and M. Açıkylldız. 2004. Kinetic modeling of liquid-phase adsorpotion and phosphate on dolomite. J. Colloid Interface Sci. 277:257-263. doi:10.1016/j.jcis.2004.04.042

Karaca, S., A. Gürses, M. Edjer, and M. Açıkyldız. 2006. Adsorptive removal of phosphate from aqueous solutions using raw and calcinated dolomite. J. Hazard. Mater. 128:273-279. doi:10.1016/j.jhazmat.2005.08.003

Kipton, H.J.P., and R.M. Town. 1992. Solubility and fractionation of humic acid; effect of $\mathrm{pH}$ and ionic medium. Anal. Chim. Acta 267:47-54. doi:10.1016/0003-2670(92)85005-Q

Lindsay, W.L. 1979. Chemical equilibria in soils. John Wiley \& Sons, New York.

Lu, W., J.L. Sibley, C.H. Gilliam, J.S. Bannon, and Y. Zhang. 2006. Estimation of US bark generation and implications for horticultural industries. J. Environ. Hortic. 24:29-34.

Mack, R., J.S. Owen, A.X. Niemiera, and J. Latimer. 2017. Virginia nursery and greenhouse grower survey of best management practices. Horttechnology 27:386-392. doi:10.21273/HORTTECH03664-17

Mangwandi, C., A.B. Albadarin, Y. Glocheux, and G.M. Walker. 2014. Removal of ortho-phosphate form aqueous solution by adsorption onto dolomite. J. Environ. Chem. Eng. 2:1123-1130. doi:10.1016/j.jece.2014.04.010

Marconi, D.J., and P.V. Nelson. 1984. Leaching of applied phosphorous in container media. Sci. Hortic. (Amsterdam) 22:275-285. doi:10.1016/0304-4238(84)90061-X

McGinnis, M.S., S.L. Warren, and T.E. Bilderback. 2009. Replacing conventional nursery crop nutrient inputs with vermicompost for container production of Hibiscus moscheutos L. 'Luna Blush.' HortScience 44:1690-1703.

Moore, P.A., Jr., and D.M. Miller. 1994. Decreasing phosphorus solubility in poultry litter with aluminum, calcium, and iron amendments. J. Environ. Qual. 23:325-330. doi:10.2134/jeq1994.00472425002300020016x

Newman, J.P., J.P. Albano, D.J. Merhaut, and E.K. Blythe. 2006. Nutrient release from controlled-release fertilizers in a neutral-pH substrate in an outdoor environment: I. Leachate electrical conductivity, $\mathrm{pH}$, and nitrogen, phosphorus, and potassium concentrations. HortScience 41:1674-1682. doi:10.21273/HORTSCI.41.7.1674

Owen, J.S., S.L. Warren, T.E. Bilderback, and J.P. Albano. 2008. Phosphorus rate, leaching fraction, and substrate influence on influent quantity, effluent nutrient content, and response of a containerized woody ornamental crop. HortScience 43:906-912. doi:10.21273/HORTSCI.43.3.906

Paradelo, R., M. Conde-Cid, M. Arias-Estévez, J.C. Nóvoa-Muñoz, E. Álvarez-Rodríguez, M.J. Fernández-Sanjurjo, and A. Núñez-Delgado. 2017. Removal of anionic pollutants by pine bark influenced by the mechanism of retention. Chemosphere 167:139-145. doi:10.1016/j. chemosphere.2016.09.158

Peters, J., S. Combs, B. Hoskins, J. Jarman, J. Kovar, M. Watson, A. Wolf, and N. Wolf. 2003. Recommended methods of manure analysis. Univ. of Wisconsin Coop. Ext. Publ. A3769. Coop. Ext. Publishing, Madison, WI.

Petrovic, M., and M. Kastelan-Macan. 1996. The uptake of inorganic phosphorus by insoluble metal-humic complexes. Water Sci. Technol. 34:253-258. doi: $10.2166 /$ wst. 1996.0629

Rich, D. 2005. The removal of total phosphorus from natural waters by precipitation. Ph.D. diss., Northwestern International Univ., Evanston, IL.

Sanyal, S.K., and S.K. De Datta. 1991. Chemistry of phosphorous transformations in soil. Adv. Soil Sci. 16:1-94.

Sholkovitz, E.R. 1976. Flocculation of dissolved organic and inorganic matter during the mixing of river water and seawater. Geochim. Cosmochim. Ac. 40:831-845.
Sinaj, S., F. Mächler, E. Frossard, C. Faïsse, A. Oberson, and C. Morel. 1998. Interference of colloidal particles in the determination of orthophosphate concentrations in soil water extracts. Commun. Soil Sci. Plant Anal. 29:1091-1105. doi: 10.1080/00103629809370011

Song, Y., H.H. Hahn, E. Hoffmann, and P.G. Weidler. 2006. Effect of humic substances on the precipitation of calcium phosphate. J. Environ. Sci. (China) 18:852-857. doi:10.1016/S1001-0742(06)60004-1

Strickland, J. 1998. The development and application of phosphorus removal from wastewater using biological and metal precipitation techniques. Water Environ. J. 12:30-37. doi:10.1111/j.1747-6593.1998.tb00143.x

Tasistro, A.S., and D.E. Kissel. 2006. Composition of aqueous extracts of broiler litter treated with aluminum sulfate, ferrous sulfate, ferric chloride and gypsum. J. Environ. Sci. Health B 41:989-1000. doi: $10.1080 / 03601230600808620$

Tiemeyer, B., N. Pfaffner, S. Frank, K. Kaiser, and S. Fieldler. 2017. Pore water velocity and ionic strength effects on DOC release from peat-sand mixtures: Results from laboratory and field experiments. Geoderma 296:86-97. doi:10.1016/j.geoderma.2017.02.024

Tyler, H.H., S.L. Warren, and T.E. Bilderback. 1996. Reduced leaching fractions improve irrigation use efficiency and nutrient efficacy. J. Environ. Hortic. 14:199-204.

USDA. 2014. 2012 Census of agriculture: Census of horticultural specialties. USDA, Washington, DC.

USEPA. 2017. Nutrient pollution: Sources and solutions. US Environmental Protection Agency, Washington, DC. https://www.epa.gov/ nutrientpollution/sources-and-solutions (Accessed 15 May 2018).

Van Moorleghem, C., L. Six, F. Degryse, E. Smolders, and R. Merckx. 2011. Effect of organic P forms and P present in inorganic colloids on the determination of dissolved $\mathrm{P}$ in environmental samples by the diffusive gradient in thin films technique, ion chromatography, and colorimetry. Anal. Chem. 83:5317-5323. doi:10.1021/ac200748e

Warncke, D.D. 1986. Analyzing greenhouse growth media by the saturation extraction method. HortScience 21:223-225.

Warren, S.L., T.E. Bilderback, and H.H. Kraus. 2001. Method of fertilizer application affects nutrient losses of controlled-release fertilizer. Acta Hortic. 548:349-356. doi:10.17660/ActaHortic.2001.548.40

Warren, S.L., T.E. Bilderback, and H.H. Tyler. 1995. Efficacy of three nitrogen and phosphorus sources in container-grown azalea production. J. Environ. Hortic. 13:147-151.

Weir, C.C., and R.J. Soper. 1963. Interaction of phosphates with ferric organic complexes. Can. J. Soil Sci. 43:393-399. doi:10.4141/cjss63-046

Wolfinger, R. 1993. Covariance structure selection in general mixed models. Commun. Statist. Simula. 22:1079-1106.

Worsfold, P., I. McKelvie, and P. Monbet. 2016. Determination of phosphorous in natural waters: A historical review. Anal. Chim. Acta 918:8-20. doi: 10.1016/j.aca.2016.02.047

Wright, A.N., A.X. Niemiera, J.R. Harris, and R.D. Wright. 1999. Micronutrient fertilization of woody seedlings essential regardless of pine bark $\mathrm{pH}$. J. Environ. Hortic. 17:69-72.

Wright, R.D., and L.E. Hinesley. 1991. Growth of containerized Eastern red cedar amended with dolomitic limestone and micronutrients. HortScience 26:143-145. doi:10.21273/HORTSCI.26.2.143

Xu, N., M. Chen, K. Zhou, Y. Wang, H. Yin, and Z. Chen. 2014. Retention of phosphorus on calcite and dolomite: Speciation and modeling. RSC Advances 4:35205-35214. doi:10.1039/C4RA05461J

Yeager, T.H., and J.E. Barrett. 1984. Phosphorus leaching from ${ }^{32} \mathrm{P}$-superphosphateamended soilless container media. HortScience 19:216-217.

Yeager, T.H., and J.E. Barrett. 1985a. Phosphorous and sulfur leaching from an incubated superphosphate-amended soilless container medium. HortScience 20:671-672.

Yeager, T.H., and J.E. Barrett. 1985b. Influence of incubation time on phosphorous leaching from a container medium. J. Environ. Hortic. 3:186-187.

Yeager,T.H., and R.D. Wright. 1982.Pinebark-phosphorus relationships. Commun. Soil Sci. Plant Anal. 13:57-66. doi:10.1080/00103628209367244

Yuan, X., W. Xia, J. An, W. Yang, and J. Yin. 2014. Removal of phosphate anions from aqueous solutions using dolomite as adsorbent. Adv. Mat. Res. 864$867: 1454-1457$.

Yuan, X., X. Wentag, J. An, J. Yin, X. Zhou, and W. Yang. 2015. Kinetic and thermodynamic studies on the phosphate adsorption removal by dolomite mineral. J. Chem. 2015:1-8. 